СТУДИЈЕ И ЧЛАНЦИ

UDC 050.488BOSANSKA VILA"1885/1914" 94(497.11)

https://doi.org/10.18485/ms_zmskij.2020.68.1.1

Др Јеленка Ј. Пандуревић

\title{
СИМБОЛИЧКО МАПИРАЬЕ КОСОВА, СТАРЕ И ЈУЖНЕ СРБИЈЕ НА СТРАНИЦАМА БОСАНСКЕ ВИЛЕ
}

У раду се прати идеолошка и политичка матрица литерарног конструисања националног идентитета у књижевном часопису Босанска вила (1885-1914). Прати се симболички топос епског Косова из аспекта уређивачке политике часописа, као и стратегија ангажовања читалачке публике у правцу идентификације са идејом српске нације засноване на језику, књижевности и традицији, односно консолидације „свих српских земаља“ на тој основи. У раду се даје приказ литерарне, историјске и етнографске заинтересованости за територије које су се у том тренутку налазиле ван граница Краљевине Србије. Избор народних пјесама, етнографске биљешке, литерарне и путописне форме, вијести и огласи, критике и коментари у функцији су доказа којим се потврђује припадност Старе Србије и Маћедоније српској нацији и посредно алудира на истовјетно „историјско“ опредјељење Срба из Босне и Херцеговине.

Кључне ријечи: Босанска вила, Косово, Стара Србија, Маћедонија, народна књижевност, публицистика, култура памћења, национални идентитет.

Босанска вила је први, најзначајнији и најдуговјечнији књижевни часопис Срба у Босни и Херцеговини (Ђуричковит 1975). Излазио је двадесет и девет година два или три пута мјесечно и доминантно обиљежио културну и политичку сцену на размеђи 19. и 20. вијека. Селективност у приступу овом изузетно обимном, тематски и жанровски разноврсном корпусу условљена

* Рад је настао у оквиру пројекта Занемарени архиви књижевног̄ и кулӣурног̄ насљеђа, који се реализује уз подршку Филолошког факултета Универзитета у Бањој Луци и Министарства за научнотехнолошки развој, високо образовање и информационо друштво Републике Српске 
је претходно најављеним и прихваћеним смјерницама ${ }^{1}$, и односи се на уочавање, односно издвајање текстова који упућују на дискурзивно обликовање косовске легенде и указују на семантички потенцијал Видовдана у оновременим идеолошким и геополитичким релацијама. Фокус је, дакле, на реконструкцији уређивачке политике часописа која се односи на мапирање свих српских земаља посредством избора и организовања текстова најразличитијег типа, при чему је народна књижевност ${ }^{2}$ имала наглашен значај и функцију (ПАндуревић 2008; 2015: 16-25). Процес промишљања ових неколико (назначених) проблемских аспеката пратио је ризик да текст буде обликован као нехомогена и диспаритетна цјелина, стога је на самом почетку било неопходно разјаснити концептуализацију кључних синтагми из наслова.

1. БОСАНСКА ВИЛА У ДУХОВНОМ ПРОСТРАНСТВУ „СВИХ СРПСКИХ ЗЕМАљА“. БОсанска вила је покренута посљедњих дана 1885. године, дакле, само неколико година након Берлинског конгреса и аустроугарске окупације Босне и Херцеговине, у условима бескомпромисне цензуре (Богићевић 1953: 441443; KRUŠEVAC 1978: 305-332) која је успостављена као важан инструмент геополитички промишљеног, инструисаног, и свим административним средствима подржаног процеса стварања босанске нације (КРАљАчић 1987: passim). Оваква стратегија Монархије произвела је, из аспекта њених империјалних претензија неприхватљиве, али и очекиване посљедице ${ }^{3}$, будући да се управо тих година на Балкану усправљала независна српска држава, као (несуђени) Пијемонт, српски и јужнословенски ${ }^{4}$. Када је ријеч о Босанској вили, цензура се у првом реду односила на обавезу избјегавања политичких и конфесионалних питања, и напомену да „треба такође пазити да у саставима забавног и поучног карактера не буде сувише наглашен српски национални елеменат“ (БЕСАРОвић 1967: 65-66). Након смрти Бењамина Калаја, креатора

\footnotetext{
${ }^{1}$ Рад је изложен у форми реферата на научној конференцији Савремена срйска фол-

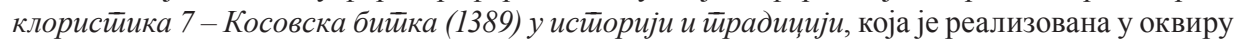
манифестације Видовдан 2019 у Крушевцу.

2 „Малобројна писмена елита малог народа, користећи се затеченим народним усменим културама као основним материјалом, нормира и стандардизује нове високе културе, да би на следећем кораку истакла захтев за сопственом државом“ (GELNER 1997: 87-93); „У томе је, дакле, главни задатак етничке интелигенције: мобилисати раније пасивну заједницу да обликује нацију око нове вернакуларне историјске културе коју је та интелигенција поново открила““ (SмІт 1998: 105).

3 Теоријски концепти студија национализма полазе од основне дихотомије у теоријском одређењу нације, и у том смислу је концепт босанске нације, заснован на категоријама административно ограничене терититорије, законом дефинисане заједнице и грађанске културе супротстављен концепту српског националног покрета у БиХ који наглашава етничке везе, вернакуларну културу, митологију, историју и народну мобилизацију.

${ }^{4}$ Метафора често употребљавана у медијском, популистичком, али и научном дискурсу (уП. СтРАњАКовић 1932; односно часопис Пијемонй који је као дневни лист излазио у Београду, у периоду 1911-1915).
} 
и заговорника стратегије стварања босанске (касније, бошњачке) нације, 1903. године, о питањима националног идентитета се све отвореније расправља и у књижевној периодици (VERVAET 2010: 1-2). Стијн Вервает сматра да је на формулацију националне реторике у периодици утицала не само већа слобода штампе, него и школовање босанскохерцеговачке интелигенције у иностраству: Бечу, Грацу, Загребу, Прагу, или ван Аустроугарске, у Београду или Истамбулу (Исто).

Историјску смјену великих сила у Босанском вилајету пратила је и експанзија свеобухватног покрета српског народа за националну консолидацију и просвјетитељски препород 5 . Босанска вила је поуздан архив за проучавање времена ${ }^{6}$ у коме је визија ослобођења, и уједињења у једну националну државу усмјеравала друштвено, културно, економско и политичко организовање Срба у Босни и Херцеговини (Цвилит 1908; BESARović 1968; PAPIĆ 1972; KRUŠEVAC 1978; MaџAP 1982; ЕкMEчИЋ 1983; KraljaČIĆ 1987; MaџAP 2001)7.

Наслањајући се на традицију српских часописа у Војводини и баштинећи идеје Уједињене омладине српске, Уредништво Босанске виле већ од првих бројева изричито и јасно наглашава неопходност етнографског рада и стварања књижевности засноване на моделу народне културе и усмене традиције. У концепцијском осмишљавању током прве године излажења (DuJMOVIĆ 2006) оно позива „све наше свештенике, учитеље и друге писмене људе“ да постану Вилини сарадници тако што ће описати „околину свог мјеста, обичаје, ношњу и говор народа, и историјске поменике“ (Бв 1886/18: 283). У европским оквирима већ помало анахрон, а у балканским очекиван и неизбјежан, романтичарски концепт народне културе и националог буђења добио је пуни замах тек на размеђу вијекова, у бурном времену геополитичког и стратешког мапирања Балкана од стране великих сила. Овај процес пратило је истовремено и имагинарно мапирање српских земаља на страницама дневне штампе и периодике. Укрштајући сегменте великих усменопоетских и књижевних наратива са путописним биљешкама и етнографским цртицама из „новооткривених“ (уп. АтАнАСовски 2014) крајева Старе и Јужне Србије, Босне и Маћедоније, исцртавале су се границе српског културног простора, уз аргументацију која би требало да буде непорецива и пресудна:

5 „Буђење нација“ на Балкану је процес који, у односу на остатак Европе, започиње много касније. Разлоге у великој мјери треба тражити у историјским околностима, односно у унутрашњем устројству Отоманске империје у којој је социјална стратификација почивала на конфесионалној, никако на националној основи.

6 У том смислу, 1907. или 1908. година узимају се као граничне. У првом периоду су доминирале етнографско-фолклористичке преокупације и идеја српског националног јединства, док су други период обиљежиле модернистичке тенденције и идеја југословенства.

${ }^{7}$ Посматрано у ширем контексту „дугог деветнаестог вијека“, експанзија и масовност штампаних медија су пресудно утицали на стварање амбијента у коме је велики број људи могао да „замисли““ (ANDERSON 1983) националну заједницу и претпостави своју припадност њој на основу језика, заједничке прошлости, културе памћења, сентимента, симбола и вриједности који имају интегративни карактер (SмIтн 1998: 310). 
Докле хвата један народ, дотле се простиру и његови обичаји, његове особине, његово мишљење, његове пјесме, приче, пословице и друге умне умотворине његове. И као што поједини крајеви једног истог народа имају различито земљиште, различно занимање и више или мање различиту прошлост, исто им тако и умотворине нису једнаке, и једна иста идеја се јавља у више различитих облика, једна иста мисао у разноме руву (...). Зато су у почетку овога века, кад је почела да се рађа слобода српска, кад је и књига српска пропевала, увиђавнији људи у народа нашега почели да купе то умно благо, те да га износе свету и предају најбољему чувару - књизи. (...) Нарочито се обраћам браћи ван граница данашње краљевине да ми се одазову, бојећи се да ми српске земље ван краљевине остану незаступљене (...). (Бв 1889/18: 285).

2. НАРАТИВНА ИМАГИНАЦИЈА, КОЛЕКТИВНА НОСТАЛГИЈА И НАЦИОНАЛНА ИДЕОЛОГИЈА: ИЗГУБљЕНА ЦАРСТВА И ПРЕДЈЕЛИ ЖУДњЕ

2.1. Косово. Већ и летимичан преглед упућује на закључак да би се уређивачка политика Босанске виле, нарочито у првом периоду (до 1907. године) могла представити на основу доприноса изградњи културног памћења посредством тематизација, ангажмана и извјештавања о догађајима који, утиснути у матрицу великих нарација, немају само локани карактер и значај, попут светосавских приредби, хуманитарних акција, оснивања задужбина, штампања књига са родољубивом тематиком. Информације о просвјетним и културним активностима различитих српских удружења, о успјесима и угледу Срба у свијету и свијетлим примјерима патриотизма, усмјерене су на консолидацију читалачке публике која своју припадност нацији заснива на светосављу, косовском завјету, слободарском отпору и идејама просвјетитељства. Нарочито су индикативни тематски бројеви посвећени јубилејима као што су стогодишњица рођења Вука Стефановића Караџића 1888. године (ПАндуревић 2017), тристагодишњица рођења Ивана Гундулића 1889, четиристо година Ободске штампарије 1893, затим стогодишњица првог српског устанка 1904, детаљно извјештавање о свечаности приликом крунисања краља Петра и сл. У позадини готово сваке свечаности, готово сваког говора Србима и о Србима, подразумијевано и патетично трепери Косово. Видовдански култ обухватио је и надахнуо све облике овог притајеног и упорног отпора аустроугарској политици, присутан у различитим контекстима, као неизоставан зачин декламованом и прокламованом патриотизму уредника и сарадника Босанске виле. У сјенци Видовдана, нарочито током „петстоте“ (1889) године обликовала се и стална рубрика под насловом Срӣске народне умойворине, позиви на претплату, прикази књига и часописа ${ }^{8}$, полемике и

8 „У овој књизи има 14 срп. нар. пјесама које је учени професор Краковског универзитета г. Коперницки превео на пољски језик, а на почетку је подужи исторични чланак од Т. Т. Јежа о Видов-дану, односно о пропасти нашој на Косову. Књига је врло укусно израђена, а посвећена је народу српском. Предложено је да се један примјерак ове књиге узида 
критике, рекламни огласи ${ }^{9}$, омажи и пригодни текстови, посредством којих би се у другачијим околностима превасходно реконструисала историја приватног живота - попут честитке коју је „српска омладина на универзитету у Пешти“ упутила добротвору Пери Дрљачи, трговцу, а коју је уредништво Босанске виле објавило у цјелини:

Врло поштовани господине!

Благо оном ко до вијек живи

Имао се рашта и родити!

Српска омладина вазда пази будним оком све оно што се догађа у појединим крајевима растуренога српства. Она се радује и одушевљава узвишеним тренуцима у животу нашега народа, а плаче са народом кад га задесе тешки удари жалосне судбе наше. И сада када се сјећа петстогодишње патње свога народа, тешки јој се уздаси отимају из груди. Ми се сјећамо, и цио народ мора се сјетити.

Кад се винемо мислима у прошлост, излазе нам пред очи свијетле слике наше негдашње славе. Ми се поносимо њима, али успомене на стару славу слабе су, да одрже један народ. Излази нам пред очи и Косово. Ми плачемо заједно са гусларем српским над тим стратиштем, на ком је закопана српска слобода и величина. Али, тешко народу који у тешким данима умије само да плаче. Славне успомене из прошлости везују нас за себе, али највише због тога, да се уз њих учимо борити за будућност своју (Бв 1889/7: 110).

У једанаестом броју Босанске виле из 1889. издваја се неколико текстова, довољно илустративних да су коментари сувишни, стога ће на овом мјесту бити представљени дескриптивно и у изводима. На насловној страници штампан је текст Прах косовских јунака, који након колективног искуства у 20. вијеку пажњу привлачи информацијама које се односе на контекст и аутора, извјесног Антонија Стражичића, „опћинског тајника на Мљету“ који на католичку чисту сриједу 1889. године потписује панегиричан текст посвећујући га „Србима без разлике вјере“. Нижу се пригодни текстови као што је одломак драме Кнез Лазар Милоша Цветића, затим цртица из српског живота под насловом Вид, поема Дионисија Миковића Косово, затим јуначка гусларска пјесма Пог̈ибија косовска и сл. У броју 12, на три стране, преноси се детаљно централна церемонија „косовске петстогодишњице у Србији“, а у наставку слиједе најаве о обиљежавању великог јубилеја у Загребу, Београду, Грацу, Паризу и Црној Гори. У наредном броју доносе се извјештаји о прославама у Сарајеву, Мостару и Чајничу:

у камен темељац у Крушевцу. Срдачна хвала браћи Пољацима на овом красном поклону и вратској љубави“ (Бв 1889/13: 208).

9 „До сада је ваљда изашла из штампе нова књига „Косово“, алегорија у четири чина с пјевањем. По народним пјесмама написао Милан Ст. Ћуричић, професор. Књига се море добити само код писца у Београду, Обренова улица бр. 9“ (Бв 1889/10: 159). 
Послије говора, друштво је отпјевало у три гласа тужну пјесму пропасти косовске: „Знате л’ сестре оно мјесто, гдје је Милош закопан“. Послије тога, декламовао је један ђак из четвртог разреда народну пјесму „Косовка дјевојка“, на опште задовољство цијеле публике; Иза овога, отпјевала су дјеца у два гласа уз пратњу друштвену пјесму „Ој Словени, још сте живи“. На пошљетку, пречасни г. прота прелио је кољиво, при том је друштво отпјевало „Вјечнаја памјат“, послије чега је г. прота опоменуо присутне да је прва врлина сјећати се својих старих предака и да ту врлину пренесу и на своје потомке. (Бв 1889/13: 208).

2.2. СТАРА СРБијА. Границе Србије у 19. вијеку нису обухватиле све области средњевјековне српске државе. Под турском влашћу, све до балканских ратова, остале су територије за које се у историографији и публицистици употребљавао појам Стара Србија. Стара Србија обухватала је Стару Рашку, Косово, Метохију, и највећи дио Вардарске Македоније, а у ширем смислу, назив се односио и на крајеве у Егејској Македонији. За рјешавање статуса ових територија након повлачења Отоманске империје биле су заинтересоване све велике силе, будући да је у питању био важан сегмент „Источног питања“, а дипломатске активности нарочито су интензивиране у времену Руско-турског рата (1877-1878) и Берлинског конгреса (1878). Краљевина Србија је улагала велике напоре да стање на терену одржава и усмјерава у српском националном интересу. На почетку XX вијека функционисала је мрежа црквено-школских општина у Косовском, Солунском и Битољском вилајету, а дипломатско-конзуларна представништва велику пажњу посвећивала су културним и просветним активностима. С друге стране, и Босанска вила је са великим интересовањем пратила и коментарисала процесе рјешавања српског националног питања, који су се у условима аустроугарске окупације и анексије могли још једино испољавати на пољу културе. У таквом контекстуалном оквиру, тема Старе и Јужне Србије присутна је на различите начине, у форми различитих књижевних, научних и публицистичких жанрова. Преглед који слиједи никако не претендује на потпуност и библиографску исцрпност. Намјера је да се указивањем на карактеристичне текстове назначе обриси уређивачке политике часописа и извори за једно (могуће) инсајдерско креирање Руританије (уп. GoldsvorTi 2000).

Значај ове теме на страницама Босанске виле недвосмислено је најављен још 1889. године, у изузетно обимном и исцрпном приказу првог издања књиге Спиридона Гопчевића Сйара Србија и Македонија, која је објављена у Бечу, на њемачком језику. Приказ је излазио у наставцима, кроз три броја, а препорука за даље читање и процјена изузетне важности ове публикације посредована је кроз напомену у којој је разоткривен цензуром условљен

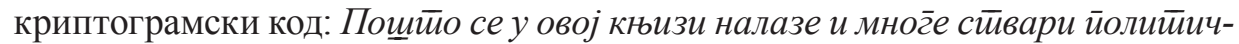

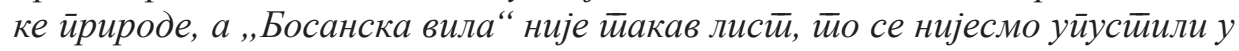
дубоку расираву, нег̄о хоћемо само да иррикажемо нащијем чийаоичма ову красну књигуу (Бв 1889/16: 254). 
Библиографски преглед усменопоетске грађе са овог терена (MAKSIMOVIĆ 1989: 49-51) показује да је и за овај корпус карактеристично инсистирање на локализацији (уп. ПАндуРЕвић 2015: 295-304). Поднаслови у оквиру рубрике Срйске народне ӥјесме гласе: Из Сйаре Србије; Из Маћедоније; Брсјачке

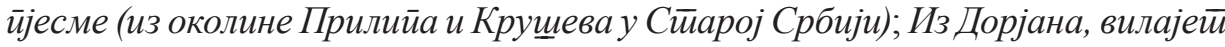
солунски; Из доњег Повардарја, Ђевђелије, Сереза... Објављене су и Срйске народне йрийовейке из Сӣаре Србије (Бв 1910/20-22: 333-334). У напоменама уз сакупљаче и казиваче налазе се подаци о локалитетима и етничкој припадности: Ову сам ӥјесму ирибиљежио 20. 8. 1889. од једнног момчетиа срииског из села Буфа щести сайи од Манастиира (Бийоља) у Маћедонији (Шар-йланина и иири чобана, Бв 1895/15: 237). Посматрано у цјелини, очекивани тематско-мотивски регистар „женских пјесама““ жанровски дефинисан као обредно-обичајни, љубавни, породични, у корпусу Босанске виле исказује и једну специфичну ноту, у смислу наглашеног условљавања личних судбина и интимних драма турским и арнаутским зулумима, хајдучким и комитским менталитетима и опредјељењима (уп. Сийница крвава; Срйска иосесиирима; Бела Неда и Ајдук Вељко; Жена ајдука Бог̄дана; Јунак и арамије; Комийска; Бв 1903/1: 14; Бв 1903/2: 34-35; Бв 1910/20-22: 332-333; Бв 1911/7-8: 122-123). Уочена специфичност може бити поетичко својство регионалне усменопоетске традиције, али и спонтани израз актуелног тренутка у коме се пјесме стварају и записују. И наравно, лични избор сарадника и уредника Босанске виле.

Осим књижевних текстова (нпр. пјесма Миладина К. Николића Расинског Срискком роду у Сйарој Србији и Маћедонији, Бв 1904/17-18: 315) и народних умотворина, објављиване су и фотографије. У броју 15. из 1889. године објављена је и панорамска фотографија Призрена (стр. 229), односно тврђаве у Призрену (стр. 233). Ове фотографије су најавиле путописно-етнографску биљешку Уз наше слике (Бв 1889/18: 285). Етнографске и историографске биљешке тематски су груписане у неколико бројева, као нпр. у броју из 1910. године, у коме се налазе и текстови: Призренски йрг̄ за срйског̄

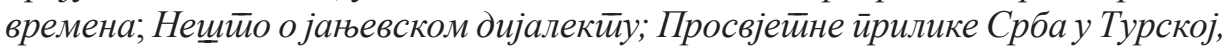
Кюижевности у Сӣарој Србији и Маћедонији и др.

Током 1892. године Бранислав Нушић је послао Уредништву Босанске виле путописну грађу која је (у наставцима) објављена под насловом „Из неуређених путничких забиљежака“" (Косово, Прищйина, Мурат̄ов грроб, Самодрежа, Вучитирн, Панӣино, Трейча, Лийљан, Село Словиње, Јањево...), чему је претходило писмо упућено главном и одговорном уреднику, Николи Кашиковићу:

Пропутовао сам у накрст Турску, пропутовао сам онај њен дио гдје живи добар и честит Србин. Доље до мора, горе до Косова, а од Вардара до албанских планина. Имам ти, мој драги Никола, тму Божју хартија и папирића; на њима је забиљежено и што сам видио и што сам чуо. Треба ми пословати годину дана да из тога створим какву цјелину, па кад 
то учиним, онда ми треба кумити годину дана кога, да ми да новца, или треба проћи још годину дана, па да таман толико зарадим, да не могу ни штампу платити. Знам ја то, а ти драги мој Никола, знаш канда још по боље. За то, велим, узећу ја ове моје биљешке, па једну по једну слаћу ти, а ти их штампај у Босанској вили (Бв 1892/2: 23).

2.3. МАЋЕДонијА. На једном мјесту у овој књизи наводи се разговор, који је Бугарин Башмаков имао с неким Енглезом који је десет година живио у Маћедонији. Тај разговор, који је објављен у Ст. Петерсбуршким Вједомостима 1899. године, гласи по писцу овако:

Како се чини Вама, да ли хришћанско становништво у Маћедонији треба рачунати у Србе или у Бугаре?

Ја мислим да су они Срби, одговори домаћин, г. Х-сон. Ја их упоређујем са становницима Босне и налазим сличност... (Бв 1910/20-22: 327) ${ }^{10}$

„Македонско питање“ је једно од најзначајнијих геополитичких жаришта на размеђи XIX и XX вијека, а сам појам требало би разумјети као ,збирно име за мноштво унутрашњих проблема који су потресали Османску империју у областима Косовског, Битољског и Солунског вилајета, односно, за дипломатску активност великих сила и балканских држава на рјешавању националног питања и будућег територијално-политичког статуса европских делова Турске“ (Антић 2017: 9). Интернационализација овог проблема, појачана након Илинденског устанка (1903), интензивирала је и активности Србије на плану школства и културне дипломатије (Антић 2017: 60-72; Новков 2014: passim).

Сарадници Босанске виле у овом периоду су не само Бранислав Нушић, српски конзул у Приштини ${ }^{11}$, и Иван Иванић, конзул у Приштини, Скопљу и Битољу, него и чланови ђачке дружине Дојчин која је 1900. године основана у солунској гимназији. Ауторитет „конзулских“ имена и функција ${ }^{12}$ усмјеравао је пажњу читалаца Босанске виле на приказе текстова које доноси Цариградски гласник ${ }^{13}$, а нешто касније и Вардар (1906-1914) ${ }^{14}$. Овај календар био је званично гласило Кола срӣских сесӣара, а његова патриотска, просвјетитељска и дидактичка провенијенција учинила га је блиским и читаоцима и сарадницима Босанске виле (Бв 1910/20-22: 339).

${ }^{10}$ Григорије Хаџи Ташковић, приказ књиге Ивана Иванића, Маћедонија и Маћедонции.

${ }^{11}$ Из овог периода Нушићевог списатељског рада су и путописи С обала Охридског̄ језера (1894) и С Косова на сиње море: белещке с йуйа кроз Арбанасе 1894. гоодине (1902). Књига Косово. Ойис земље и људи (1902) заснована је на етнографским и путописним биљешкама, али стилом и интенцијама претендује да остави утисак научне расправе.

12 Што није била препрека Уредништву да у посљедњем броју из 1910. године објави изузетно негативно интонирану критику Иванићеве књиге Маћедонија и Маћедонци.

${ }^{13}$ Једино српско гласило у Турској (1895-1909), излазио на српском језику. У једном периоду уређивали су га Делфа и Иван Иванић.

${ }^{14}$ Бв 1910/20-22. 
Многобројни чланци из књижевности, историје и етнологије, информације о просвјетним и културним дешавањима (уп. СимијАновит 2008: 191-201), као и дипломатским активностима градили су динамичан и живописан мозаик на коме се уобличавала слика Маћедоније као српске земље.

Солидарност са становништвом Старе Србије и Маћедоније, уз пуно разумијевање проблема насталих ослобађањем ових крајева, уредништво Босанске виле наглашавало је у неколико наврата, у бројевима који су имали обиљежја „тематских“. Данас непознати сакупљачи, из Скопља, Битоља, Куманова, Кичева, Прилепа, Крушева, Велеса и других мјеста слали су уредништву „Српске песме из Маћедоније“ и „Маћедонске народне песме“, приповијетке и загонетке из „Старе Србије“ и „Маћедоније“ које је уредништво најавило ријечима: Доносимо ове маћедонске народне йјесме, да се види, е је и у юима йрадииија срйска. У маћедонским народним ијјесмама нема буг̄арске йрадииије, щито је, сјем остиалих, један доказ вище да Маћедонщи нису Буг̄ари, већ - Срби (Бв 1903/1: 14).

Славянскїи В(јат)кь“ јавља, да је руска академија наука закључила да љетос пошаље у Маћедонију научну експедицију, која ће се на лицу мјеста увјерити о становништву Маћедоније, да ли је српско, или бугарско. Она ће проучити Маћедонију у погледу језика и старина. У експедицији су: професор и историк Миљуков (бугарофил), Кондаков, византинист, и Лавров, слависта. Читамо да ће се овој експедицији придружити бугарски научењаци, а српски чекају готовога посла. Ми би упутили ту експедицију да прочита народну пјесму у прошлом броју нашега листа „Собет цара и везира“, па ће и без испитивања знати да у Маћедонији живе Срби. (Бв 1900/12: 166)

Приповједна грађа обухваћена је поднасловима Срйска народна йрийоветика из Бийоља (Бв 1906/4: 60-61; Бв 1906/5: 78; Бв 1908/14: 221-223; Бв 1908/24: 380-381; Бв 1908/26: 411-413), Срйске народне заг̄онетике (из Маћедоније, у околини Кичева) објављене су 1893 (Бв 1893/4-5:63), а Срйске народне иииталице из Маћедоније 1910. године (Бв 1910/20-22: 333). Највише лирских пјесама, из властите збирке Маћедонске народне иесме послао је Иван Иванић, затим Д. Николић који је у Босанској вили објављивао пјесме под заједничким називом Срйске народне иесме из Маћедоније. Женске ијјесме, и Анђелко Јанковић, чија збирка носи наслов Брсјачке ӥјесме (из околине Прилийа и Крущева у Сйарој Србији). Срйске народне ирийовейке из Бийоља потписао је као сакупљач Лазар Мишковић, а међу сакупљачима се налазе и имена Илије Димковића, Станоја Мијатовића, Јована Митриновића, Томе Јанаћијевића и других.

Пјесма Бощъъак јунак објављена је у 9. броју 1903. године, а записао ју је Коста Димчевић у Дојрану, вилајет Солунски. То је риједак и драгоцјен примјер „стиховане бајке“, изузетно архаичне садржине. Ипак, чини се да је пјесма Бощъ ак јунак у Босанској вили објављена више због провокативног наслова и контекста у коме се нашла, него због непоновљивог тематско-мотивског 
склопа и инспиративне архаике којом се више од стотину година касније наметнула као грађа за читав један рад (ПАндуревић 2008).

3. ЕПИСТЕМОЛОШКО МАПИРАњЕ САВРЕМЕНЕ СРПСКЕ ФОЛКЛОРИСТИКЕ: ЧАСОПИСИ КАО АРХИВИ КњИЖЕВНОГ И КУЛТУРНОГ НАСљЕЪА. ПроУчаВање КњИЖеВНе ПерИодике је веома изазовно са становишта историје књижевности и историје идеја, културне политике и културног памћења. С тим у вези, на одабраном корпусу Босанске виле разматрани су концепти измишљања традиције и мапирања национлног идентитета. Измишљање традиције (НоBSBOм и др. 2011) схваћено је у складу са истоименим теоријским концепцијама, не као индивидуалан и нечастан чин у домену мистификација и фалсификата него, превасходно, као пројектовна активност с циљем осмишљавања, одржавања, промовисања и проблематизовања националног идентитета путем етнографске и публицистичке дјелатности. Уређивачка политика Босанске виле била је усмјерена на животне и актуелне проблеме српског народа на Балкану, и нарочито, на стварање духовне и културне климе која би омогућила друга и другачија рјешења за српски народ у Босни и Херцеговини. Укључивање у савремене токове књижевне, културне, просвјетитељске и политичке мисли схваћено је као „визија и мисија“ малобројне, али изузетно активне и ангажоване заједнице српских интелектуалаца у Босни и Херцеговини. Дистрибуцијом часописа, изградњом мреже пренумераната и сарадника, избором садржаја и тема, обиљежавањем јубилеја из националне историје, те критичким коментарима у области књижевне, научне и публицистичке дјелатности, стварао се имагинарни оквир „свих српских земаља“ и испољавао досљедан грађански активизам српске заједнице у условима политичке цензуре. „Босанска вила ће“, како пише Мухсин Ризвић, „у току три деценије свог излажења, пратити и обликовати културни развој и друштвени живот Срба у Босни и Херцеговини, представљајући, под фирмом књижевног и породичног часописа, национално-културну одбрану од насртаја туђинске културе и покушаја одрођавања, али и одређену платформу националне политике. (...) Фреквенцијом српског имена и афирмацијом српских културних и књижевних вриједности, штитила је Србе од асимилације и развијала њихову националну свијест“" (Ризвић 1992: 25).

Проучавање часописа као специфичних архива који нуде увид у најразличитије аспекате приватног и јавног живота (из домена културне презентације и свакодневице, погледа на свијет, политика, односно стратегија којима се обликује јавно мњење и консолидује читалачка публика, реконструишу бинарне структуре на релацији „ми/они“, „,вој/туђи“ итд.) представља кључ истинског разумијевања епохе чије рефлексе, животно и упечатљиво, уочавамо и након више од једног вијека. И у том смислу, проучавања и разумијевања етничких колективитета изван премодерног контекста, креирање и мапирање „знања о народу“ и националног памћења у условима масовне културе и конкретних друштвених, историјских и политичких околности, представљају један од магистралних токова савремене српске фолклористике. 


\section{ИЗВОРИ И ЦИТИРАНА ЛИТЕРАТУРА}

Антић, Дејан. Полийичке йрилике и срӣски народ у Вардарској Македонији (1903-1912). Докторска дисертација. 2017. <http://nardus.mpn.gov.rs/handle/123456789/8532> 27. 1. 2020.

БВ: Босанска вила. Лист за забаву, поуку и књижевност. Сарајево, 1885-1914.

Богићевић, Војислав. Улога књижевних часописа у БиХ у доба Калајевог режима (1882-1902). Живот̄ (1953): 438-443.

Ђуричковић, Дејан. Босанска вила 1885-1914. Сарајево: Свјетлост, 1975.

Екмечић, Милорад. Ист̄орија срӣског̄ народа, књ. VI, том 1. Београд: Српска књижевна задруга, 1983.

МАџАР, Божо. Покрет̄ Срба БиХ за вјерску и йросвјет̄ну самоуйраву. Сарајево: Веселин Маслеша, 1982.

МАџАР, Божидар. Просвјет̄а, СПКД 1902-1949. Бања Лука - Српско Сарајево, 2001. Новков, Александра. Средње срйске щкколе у Османском царсииву (1878-1912). Докторска дисертација. <http://nardus.mpn.gov.rs/bitstream/handle/123456789/8129/ Disertacija9344.pdf $>$ 27. 1. 2020.

Нушић, Бранислав. Косово, ойис земље и народа. Издање са сликама. Нови Сад: Матица српска, 1902.

Нушић, Бранислав. С Косова на сиње море. Београд: Чигоја, 2005.

ПАндуРевић, Јеленка. Објављивање народних умотворина у Босанској вили као вид

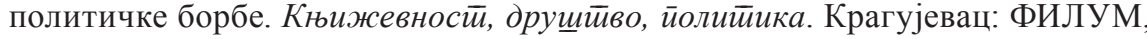
2008, 187-197.

ПАндУРевић, Јеленка. Из фолклорне ризнице Босанске виле: ейско-лирске ӥјесме. Нови Сад - Београд - Бања Лука: Матица српска - Институт за књижевност и уметност - Друштво чланова Матице српске у Републици Српској, 2015.

ПАндуревић, Јеленка. Вукови сљедбеници у Босанској вили. За и йройив Вука 2. Сава Дамјанов (ур.). Београд: Службени гласник, 2017.

Ризвић, Мухсин. Улога редакције у књижевном одређењу часописа Босанска вила. Традиционално и модерно у срӣским часойисима на йочейку века (1895-1914). С. Пековић и В. Матовић (ур.). Нови Сад - Београд: Матица српске - Институт за књижевност и уметност, 1992, 23-37.

Симјановић, Јован. Календар Вардар о Старој Србији. Башииина 24 (2008): 191-200. СтрњАковић, Драгослав. Србија, Пијемонй Јужних Словена 1842-1853. Београд: Народна штампарија, 1932.

Anderson, Benedict. Imagined Communities. Reflections on the Origin and Spread of Nationalism. Rev. Ed. London: Verson, 1983.

AtAnASOvsKi, Srđan. Upoznaj Staru Srbiju da bi je... zavoleo. Beton IX/151 (16. septembar 2014). $<$ http://www.elektrobeton.net/wp-content/uploads/2014/09/BETON_151.pdf> 27. 1.2020. 
Besarović, Risto. Kultura i umjetnost u Bosni i Hercegovini pod Austrougarskom upravom.

Sarajevo: Arhiv BiH, 1968.

Besarović, Risto. Iz kulturnog života u Sarajevu pod austrougarskom upravom. Sarajevo:

Veselin Masleša, 1974.

Dusmović, Sonja. Između tradicije i modernizacije - Bosanska vila u prvoj godini izlaženja

(1886). Separat iz Priloga br. 35. Sarajevo: Institut za istoriju u Sarajevu, 2006.

Gelner, Ernest. Nacije i nacionalizam. Novi Sad: Matica srpska, 1997.

Goldsvorti, Vesna. Izmišljanje Ruritanije. Beograd: Geopoetika, 2000.

НовSвом, E і T. Rejndžer T. (eds.). Izmišljanje tradicije. Beograd: Biblioteka XX vek, 2002.

Kraljačić, Tomislav. Kalajev režim u Bosni i Hercegovini (1882-1903). Sarajevo: Svjetlost, 1987.

KruŠEvaC, Todor. Bosanska vila. Bosanskohercegovački listovi u XIX veku. Sarajevo: Svjetlost, 1978.

MAKsımović, Vojislav. Makedonske narodne umotvorine u časopisu Bosanska vila (sa bibliografskim prilogom). Bibliotekarstvo, Godišnjak Društva bibliotekara Bosne $i$ Hercegovine za 1988. XXXIV (1989): 47.

PAPIĆ, Mitar. Školstvo u BiH za vrijeme Austro-Ugarske okupacije (1978-1918). Sarajevo: Veselin Masleša, 1972.

Smit, Antoni. Nacionalni identitet. Beograd: Biblioteka XX vek, 1998.

VERVAET, Stijn. Između hrvatstva, srpstva i panislamizma: književna periodika i izgradnja nacionalnog identiteta bosanskih muslimana uoči Prvog svetskog rata. 2010. <https:// biblio.ugent.be/publication/1092894/file/6745134> 27. 1. 2020.

Vervaet, Stijn. Centar i periferija u Austro-Ugarskoj. Dinamika izgradnje nacionalnih identiteta u Bosni i Hercegovini od 1879. do 1918. godine na primjeru književnih tekstova. Zagreb i Sarajevo: Synopsis, 2013.

Jelenka J. Pandurević

\section{SYMBOLIC MAPPING OF KOSOVO, OLD AND SOUTH SERBIA IN THE JOURNAL BOSANSKA VILA}

\section{Sum mary}

Using a selected sample, the paper presents a complex activity of the literary construction of the national identity in the literary journal Bosanska vila (1885-1914). This popular and influential journal was one of the most significant centres of literary, ethnographic and educational work, while its relatively stable editorial policy was designed towards the homogenization and strengthening of national awareness. The paper presents the literary, historical and ethnographic interest for the territories inhabited by Serbs, which were at that time beyond the borders of the Kingdom of Serbia. The authors indicate literary and publicist intensification of epic Kosovo and, in connection with that, a strategy 
of engaging literary audience towards identifying with the idea of the Serbian nation based on language, literature and tradition. The selection of folk poems, ethnographic notes, literary and travel forms, news and advertisements, criticism and commentary serve the function of proving that Old Serbia and Macedonia belong to the Serbian nation and indirectly refers to the same "historical" choice of Serbs from Bosnia and Herzegovina.

Катедра за србистику

Филолошки факултет

Универзитета у Бањој Луци

jelenkapandurevic1@gmail.com 